\title{
Article
}

\section{The Effects of Flipped Learning Approaches in Anatomy Class}

\author{
Younghui Hwang ${ }^{1(1)}$ and Jihyun $\mathrm{Oh}^{2, *}$ \\ 1 Department of Nursing, College of Medicine, University of Ulsan, Ulsan 44610, Korea; hyh77@ulsan.ac.kr \\ 2 Department of Nursing, Daejeon University, Daejeon 34520, Korea \\ * Correspondence: jihy0123@dju.kr; Tel.: +82-42-280-4652
}

Citation: Hwang, Y.; Oh, J. The Effects of Flipped Learning Approaches in Anatomy Class. Sustainability 2021, 13, 13724. https:/ / doi.org/10.3390/su132413724

Academic Editor: Juan

Carlos Bustamante

Received: 13 September 2021

Accepted: 10 December 2021

Published: 13 December 2021

Publisher's Note: MDPI stays neutral with regard to jurisdictional claims in published maps and institutional affiliations.

Copyright: (C) 2021 by the authors. Licensee MDPI, Basel, Switzerland. This article is an open access article distributed under the terms and conditions of the Creative Commons Attribution (CC BY) license (https:// creativecommons.org/licenses/by/ $4.0 /)$.

\begin{abstract}
Pedagogical innovations applying flipped learning models are being applied in nursing education. The aim of this study was to verify the effects of the flipped learning approach in an anatomy class among undergraduate nursing students. This was a non-randomized controlled study. Of 154 nursing students enrolled in an anatomy class in South Korea, 79 were in the lecture-based group and 75 were in the flipped learning group. Data were collected using structured questionnaires. Problem solving ability and self-leadership improved significantly in the flipped learning group after the intervention but decreased in the lecture-based group. There was no difference in critical thinking between the flipped learning and control groups. The participants in the flipped learning group were more satisfied with the class than those in the lecture-based group. Flipped learning facilitates interactive activities that support the needs of advanced learners and provide more opportunities to develop problem-solving abilities and self-leadership.
\end{abstract}

Keywords: flipped learning; critical thinking; problem solving ability; self-leadership; class satisfaction; nursing student

\section{Introduction}

Healthcare is expected to change a lot in the future due to the development of diverse new technologies such as artificial intelligence, big data, and wearable internet technology [1,2]. In nursing education, it is important to train nurses to provide appropriate nursing services to patients in line with the changing healthcare environment [3]. In particular, it will be necessary to prepare nurses to handle an unparalleled amount of information and new technologies, as well as solve patients' health problems using these new approaches $[1,3]$. It will also be necessary to develop leadership capabilities so that nurses can play a leading role in providing new healthcare services via new technologies [3].

The more active learning approaches such as simulation-based learning, problembased learning, team-based learning, and flipped learning have recently been attempted in nursing education to improve core competences in nursing, such as problem-solving ability, critical thinking, and self-leadership [4-8]. However, nursing students may be resistant to active learning methods due to their unfamiliarity and increased effort, both before and during class [9]. Nursing students, at least in the early stages of their training, generally prefer direct, concrete, lecture-centered learning to new educational approaches [10].

Anatomy is a basic subject that nursing students study in the early stages of their training. Applying flipped learning in anatomy classes can help nursing students familiarize themselves with active learning methods in a simple setting without burdening them [11]. Flipped learning reverses existing methods [12,13] by expecting students to study by themselves at home before class by viewing online video lectures. In class, students solve problems that they did not understand during online learning and participate in deep learning sessions or activities with the help of instructors [14].

In flipped learning, professors play the role of facilitators, and learners acquire higherlevel knowledge by leveraging their own knowledge, skills, and strategies to solve a given task or problem autonomously and actively [13]. Therefore, flipped learning can 
improve self-control and self-leadership by allowing students to engage in self-directed learning $[15,16]$ and think critically by searching for information and resources to solve a given problem or task. Flipped learning can also improve problem-solving ability by requiring students to analyze inferences and information to reach learning goals [17,18].

Flipped learning is known to be an appropriate educational method for improving nurses' core competencies such as critical thinking, problem-solving ability, and selfleadership [15-18]. Critical thinking encompasses the reflective and analytical processes found in clinical reasoning $[19,20]$, while problem solving represents the action-end depending on these critical thinking processes [19]. Therefore, critical thinking and problemsolving ability are essential to nurses for assessing, comparing, analyzing, reflecting, judging, and solving patients' health problems. Self-leadership is also necessary for discovering and organizing opportunities that lead to useful change [21].

Little research has been conducted on whether flipped learning in an anatomy class can improve critical thinking, problem-solving ability, and self-leadership. Thus, determining if flipped learning improves these aspects is important and may lead to active learning approaches in the future. This study attempted to identify whether flipped learning in an anatomy class can improve critical thinking, problem-solving ability, self-leadership, and class satisfaction among nursing students.

\section{Theoretical Background and Hypothesis Development}

\subsection{Flipped Leaning and Critical Thinking}

Critical thinking is the mental process of recognizing, analyzing, synthesizing, and evaluating information collected through observation, experience, reflection, reasoning, and communication to make decisions for action [22]. Nursing students can make decisions and solve nursing problems through critical thinking [20]. As critical thinking is the basis for clinical reasoning [20], it is important to educate nursing students to improve their critical thinking. Flipped learning is an effective learner-centered teaching method to improve critical thinking [18], and applying flipped learning in a medical-surgical nursing course improved nursing students' critical thinking compared to traditional lectures [23]. Therefore, it can be predicted that applying flipped learning in an anatomy class can improve nursing students' critical thinking skills compared to traditional lectures.

Various opinions have been presented on the components of critical thinking, and Yoon [24] developed a tool to measure the critical thinking of nursing students based on concepts commonly presented among the components of critical thinking. This tool consists of questions that can measure whether conclusions have been drawn carefully through a logical process based on reasonable evidence with healthy skepticism and intellectual eagerness/curiosity [24].

Hypothesis 1 (H1). Participants in a flipped learning group will have higher critical thinking compared to those in a lecture-based group.

\subsection{Flipped Leaning and Problem-Solving Ability}

Problem-solving identifies a problem and implements decisions reached through critical thinking [19]. As problem-solving ability can provide targeted solutions for nurses to analyze effectively patients' health problems and implement nursing intervention plans [25], it is essential to improve the problem-solving ability of nursing students. As flipped learning can utilize methods such as the integration of team-based learning and clinical scenarios, applying flipped learning in surgical nursing practicum could improve nursing students' problem-solving ability [6]. Therefore, applying flipped learning in anatomy classes can help nursing students improve their problem-solving ability.

In this study, the tool developed by Lee et al. [26] to measure the problem-solving ability of adults, and the validity and reliability of which has been verified, was used. This tool measures problem-solving ability by dividing it into five areas: clarifying problems, seeking a solution, decision making, applying the solution, and evaluation and reflection. 
This tool consists of questions that measure the problem-solving process of clarifying the nature of the problem, seeking solutions, making decisions based on them, performing solutions, and evaluating and reflecting on the results when we solve problems encountered in everyday life or in a specific situation.

Hypothesis 2 (H2). Participants in a flipped learning group will demonstrate higher problemsolving ability after flipped learning education compared to those in a lecture-based group.

\subsection{Flipped Leaning and Self-Leadership}

Self-leadership is the process in which individuals regulate their behavior while motivating themselves toward change and growth. Behavior, cognition, and compensation strategies are used to achieve goals [27]. Self-leadership could have an effect on nursing skills because it affects the individual's ego to improve individual abilities and offer flexible nursing practices [28]. Applying flipped learning in a surgical nursing practicum improved goal setting among components of nursing students' self-leadership [6]. Various activities of flipped learning, such as increased interaction with team members, curiosity, and feedbackseeking activities can improve nursing students' ability to recognize learning objectives and to set goals $[6,29]$. Therefore, it can be assumed that applying flipped learning in an anatomy class can improve the self-leadership of nursing students.

The self-leadership measurement tool [30] used in this study consists of questions that measure behavior-focused strategies, constructive thought pattern strategies, and natural reward strategies. Behavior-focused strategies aim to set appropriate goals and provide motivation and feedback for successful implementation. Constructive thought pattern strategies can modify ways of thinking and thinking patterns to positively affect work and activities. Natural reward strategies are intended to produce motivation through the positive aspects of work and activities, and to reinforce behavior using associated reward.

Hypothesis 3 (H3). Participants in a flipped learning group will show higher self-leadership compared to those in a lecture-based group.

\subsection{Flipped Leaning and Class Satisfaction}

Course evaluation is necessary to evaluate the curriculum and to provide educators with feedback necessary to improve the efficiency of teaching and learning [31]. Course evaluation is a complex activity that can evaluate various dimensions in this study; class satisfaction was measured using the overall evaluation among the dimensions established by Lee [32]. Class satisfaction consisted of the following three questions: "I am generally satisfied with this class", "I will recommend this class to other students", and "I have increased interest in the relevant academic field through this course".

Flipped learning increased class satisfaction by providing learners with useful learning experiences and allowing learners to participate effectively in discussions [33]. Therefore, applying flipped learning in an anatomy class will help increase class satisfaction.

Hypothesis 4 (H4). Participants in a flipped learning group will have higher class satisfaction than those in a lecture-based group.

\section{Materials and Methods}

\subsection{Study Design and Participants}

We performed a non-randomized controlled trial to explore the learning efficiency of a flipped learning approach in an anatomy class among nursing students. Participants were assigned randomly to either the flipped learning group or the lecture-based group. The study participants were nursing students who took anatomy classes at two South Korean universities (denoted $\mathrm{K}$ and $\mathrm{U}$ ). These two universities offer the same type of nursing degree and run a similar curriculum. Both universities were similar with respect to curriculum materials and educational services. Potential participants were assessed based 
on the following inclusion criteria: they voluntarily agreed to participate in this study [20]; they had enrolled in the Anatomy learning practicum for the first time [20]; they had no previous experience with flipped learning [20].

A total of 161 participants who met these criteria were enrolled in this study. In the flipped learning group, 77 nursing students who had registered for the anatomy class using flipped learning at $\mathrm{K}$ university in South Korea were recruited as the experimental group in 2018, while the lecture-based group included 84 nursing students who took the anatomy class at $U$ university as the control group in 2018. Five participants in the control (lecture) group and two participants in the flipped learning group who did not fill out the questionnaires completely were excluded from the final analysis. Finally, there were 79 participants in the lecture-based group and 75 participants in the flipped learning group, for a total of 154 students included in the final analysis. Regarding the homogeneity between the experimental group and control group, we specifically considered homogeneity for the general characteristics and dependent variables in the two groups (Tables 1 and 2). Additionally, the instructors in both groups periodically helped their students understand the lesson contents and confirmed time schedules with each other. Participants in both groups received the same educational process with the same textbooks.

Table 1. General characteristics of participants and comparison of homogeneity for general characteristics between the flipped learning and lecture-based groups $(\mathrm{N}=154)$.

\begin{tabular}{|c|c|c|c|c|}
\hline \multirow[t]{2}{*}{ Variables } & \multirow[t]{2}{*}{ Categories } & $\begin{array}{l}\text { Flipped Learning Group } \\
\qquad(n=75)\end{array}$ & $\begin{array}{l}\text { Lecture-Based Group } \\
\qquad(n=79)\end{array}$ & \multirow[t]{2}{*}{$t$ or $\chi^{2}(p)$} \\
\hline & & \multicolumn{2}{|c|}{$n(\%)$ or Mean $\pm \mathrm{SD}$} & \\
\hline Age & & 18.67(1.34) & 19.32(1.43) & $-2.883(0.005)$ \\
\hline Gender & $\begin{array}{c}\text { Female } \\
\text { Male }\end{array}$ & $\begin{array}{l}64(85.3) \\
11(14.7)\end{array}$ & $\begin{array}{c}70(88.6) \\
9(11.4)\end{array}$ & $0.365(0.634)$ \\
\hline Satisfaction with major & $\begin{array}{l}\text { Satisfied } \\
\text { Neutral }\end{array}$ & $\begin{array}{l}52(69.4) \\
23(30.6)\end{array}$ & $\begin{array}{l}51(64.6) \\
28(35.4)\end{array}$ & $0.40(0.608)$ \\
\hline Satisfaction with school life & $\begin{array}{l}\text { Satisfied } \\
\text { Moderate }\end{array}$ & $\begin{array}{l}44(58.7) \\
31(41.3)\end{array}$ & $\begin{array}{l}46(58.2) \\
33(41.8)\end{array}$ & $0.00(0.956)$ \\
\hline
\end{tabular}

Table 2. Comparison of homogeneity for dependable variables between the flipped learning and lecture-based groups on the pre test $(\mathrm{N}=154)$.

\begin{tabular}{cccc}
\hline & & $\begin{array}{c}\text { Flipped Learning Group } \\
(\boldsymbol{n}=\mathbf{7 5 )}\end{array}$ & $\begin{array}{c}\text { Lecture-Based Group } \\
(\boldsymbol{n}=\mathbf{7 9 )}\end{array}$ \\
\cline { 2 - 4 } Variables & \multicolumn{3}{c}{$\boldsymbol{t}$} \\
Critical thinking & $3.60 \pm 0.29$ & $3.60 \pm 0.40$ & $0.04(0.972)$ \\
Problem-solving ability & $3.52 \pm 0.42$ & $3.62 \pm 0.50$ & $-1.29(0.198)$ \\
Clarifying a problem & $3.73 \pm 0.46$ & $3.80 \pm 0.52$ & $-0.88(0.381)$ \\
Seeking a solution & $3.57 \pm 0.51$ & $3.62 \pm 0.59$ & $-0.47(0.637)$ \\
Decision making & $3.56 \pm 0.52$ & $3.71 \pm 0.65$ & $-1.54(0.126)$ \\
Applying a solution & $3.51 \pm 0.53$ & $3.57 \pm 0.51$ & $-0.71(0.479)$ \\
Evaluation and reflection & $3.21 \pm 0.61$ & $3.37 \pm 0.75$ & $-1.30(0.165)$ \\
Self-leadership & $3.54 \pm 0.38$ & $3.52 \pm 0.44$ & $0.22(0.825)$ \\
Behavior-focused strategies & $3.65 \pm 0.43$ & $3.63 \pm 0.47$ & $0.20(0.839)$ \\
Natural reward strategies & $3.25 \pm 0.63$ & $3.17 \pm 0.68$ & $0.81(0.421)$ \\
Constructive thought pattern strategies & $3.49 \pm 0.55$ & $3.50 \pm 0.56$ & $-0.18(0.855)$ \\
\hline
\end{tabular}

Sample size was estimated using the G power 3.1.4 program [34]. According to our analysis, 126 participants were needed (63 in each group) to yield statistical power of 0.80 , effect size of 0.50, and two-sided level of significance of (alpha) 0.05 . Therefore, the actual sample size was adequate. 


\subsection{Measures}

Critical thinking was measured with a tool developed by Yoon [24] on a 5-point Likert scale with 27 items ranging from $1=$ "not at all" to $5=$ "very much," in which higher scores mean greater critical thinking abilities. Cronbach's $\alpha$ in Yoon [24] was 0.84, and in this study was 0.85 , indicating acceptable internal consistency.

Problem-solving ability was measured with a tool developed by Lee et al. [26]. The scale comprises 30 items, with five items for each of the following subscales: clarifying a problem, seeking a solution, decision making, applying the solution, and evaluation and reflection. Each item is rated on a 5-point Likert scale from 1 ("very rarely") to 5 ("very frequently"). A higher score indicates higher problem-solving ability. Cronbach's $\alpha$ in Lee et al. [26] was 0.93 , and in this study it was 0.93 , indicating high reliability.

The self-leadership scale developed by Houghton and Neck [35] was adapted as a validated Korean version by Shin et al. [30]. The validated Korean scale was used to measure the degree of self-leadership among nursing students. The tool consists of a 35-item questionnaire comprising three dimensions: behavioral focused strategies, natural reward strategies, and creating constructive thought pattern strategies. Each item is rated on a 5-point Likert scale ranging from $1=$ "strongly disagree" to $5=$ "strongly agree." The possible score range is 10-40; a higher score indicates better self-esteem. Cronbach's $\alpha$ in Shin et al. [30] was 0.87 , and in this study was 0.89 , indicating high reliability.

Class satisfaction was measured using a modified instrument based on that developed by Lee [32]. The scale comprises 3 items and each item is rated on a 5-point Likert scale from 1 ("not satisfied") to 5 ("extremely satisfied"). A higher score indicates higher class satisfaction. Cronbach's $\alpha$ in Lee [32] was 0.84 , and in this study was 0.94 , indicating high reliability.

\subsection{Procedures}

The study was conducted between 5 March and 17 June 2018 at two universities in South Korea. This study was designed to explore the effects of flipped learning in an anatomy class taken by nursing students in South Korea. The participants were nursing students enrolled in an anatomy class at both universities. No participants had engaged in flipped learning before the experiment. The design of this study is described in Figure 1. The two groups consisted of a flipped learning group and a lecture-based group. The anatomy class was administered to each group as a weekly 2-h class for 15 weeks. Following the ADDIE model (analysis, design, development, implementation, and evaluation) [36], we developed a flipped teaching method for the anatomy class (Figure 2). Researchers received written informed consent for participation in research from every study participant. Instructors of both groups prepared a brief orientation and gave students identical lecture handouts during the week before class began. It was mandatory for students in the flipped learning group to attend online lectures in advance. The flipped learning group could focus on each main lesson as many times as they wanted by accessing e-learning lectures at home. After the flipped learning group had learned through online lectures, they were required to attend in-person classes that included group activities, such as discussion, problem solving, and feedback. Instructors answered student questions during class, and covered all content in class via questions and discussions. In the traditional lecture-based group, students listened to in-person lectures by their instructors during class, followed by question-and-answer sessions. In-class activities, multiple-choice examinations, and quizzes were conducted in both groups. After class, homework assignments were used to evaluate learning in each group, and final exams were given to both groups during the final week of class. The pre test was administered on the first day of an anatomy class, and the post test was administered at the end of the 15-week class. 
Flipped learning group $(n=75)$ lecture-based group $(\mathrm{n}=79)$

Orientation on the first week

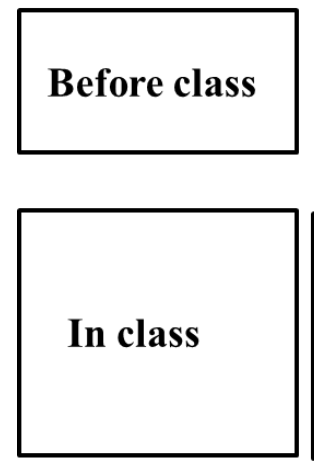

\section{Online lectures}

Lecture handout

\section{Exam, quiz}

Group activities ( ie., group discussion, group problem solving, feedback)

Face-to-face instruction

Exam, quiz

Question-and-answer session

Homework, final exam

Figure 1. Research design.

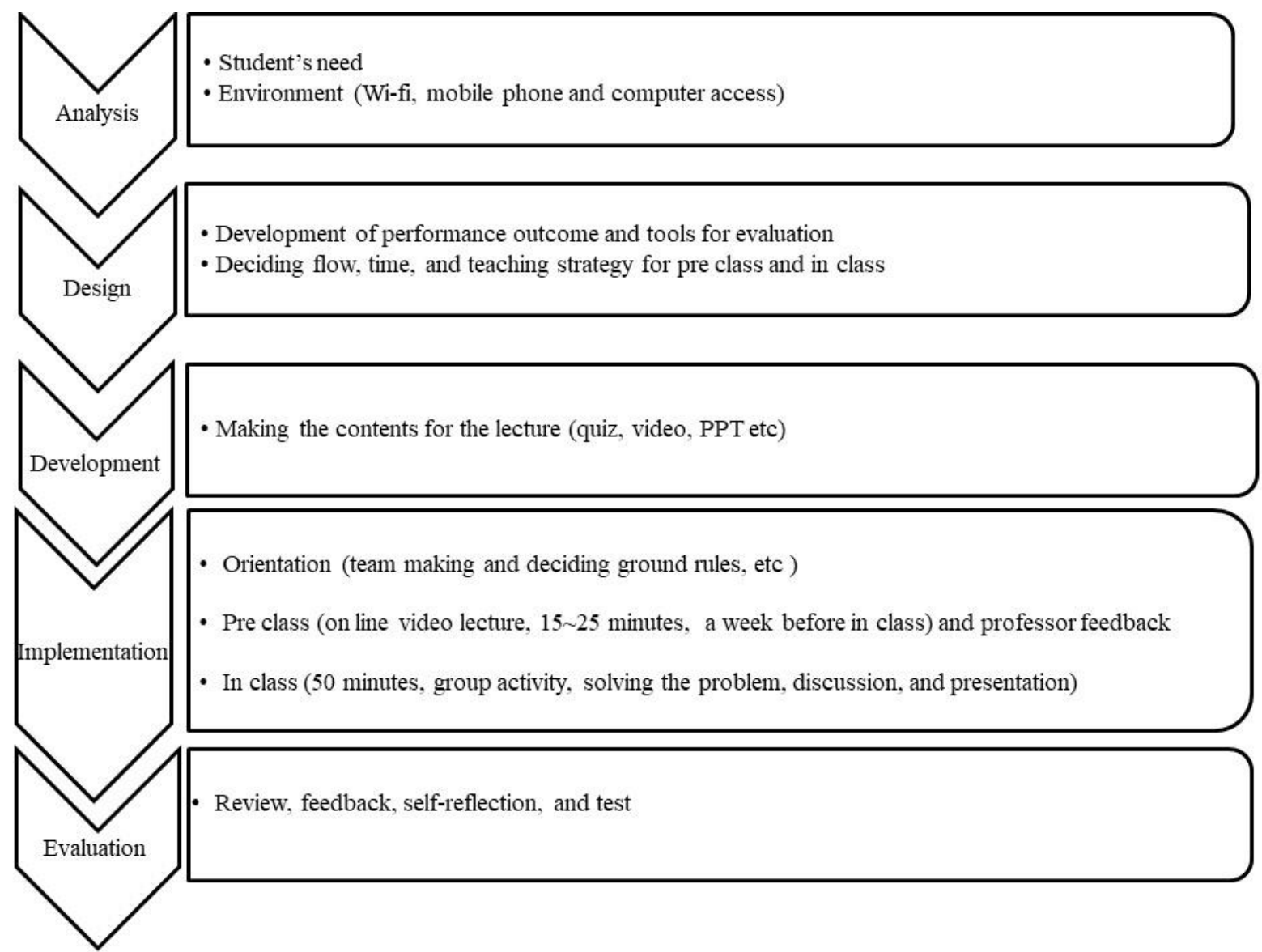

Figure 2. Development of intervention based on the ADDIE Model (analysis, design, development, implementation, and evaluation). 


\subsection{Data Analysis}

The collected data were analyzed using SPSS version 23.0 for Windows. The characteristics of the participants were analyzed by using frequencies and percentages, means, and standard deviation values. Independent t-tests and chi-square tests were conducted to examine the homogeneity of the two groups pre-intervention. Independent $t$-tests were used to compare pre-post differences in critical thinking, problem solving ability, and self-leadership between the flipped learning and lecture-based groups. In order to confirm the between-groups effect and the inner-group effect, a mixed model was performed considering repetition, and an independent $t$-test was conducted on the variables with significant interaction to confirm the difference in change.

\subsection{Ethical Considerations}

This study was conducted after approval by the Institutional Review Board of K university. All participants were informed about the aims and plan of the study, and written consent was obtained from all study participants prior to their participation. All participants could withdraw their consent at any time without negative consequences or limitations affecting their learning or academic grade.

\section{Results}

\subsection{Participant Characteristics}

The study included 154 nursing students (75 in the flipped learning group and 79 in the lecture-based group). The mean age of the flipped learning and lecture-based groups was $18.67 \pm 1.34$ and $19.32 \pm 1.43$ years, respectively $(t=-2.883, p=0.005)$. The characteristics of the participants are displayed in Table 1 . Most participants were female $(85.3 \%)$ and more than half of the participants were satisfied with their major $(69.4 \%)$ and college life $(58.7 \%)$. There were no statistically significant differences in gender $(p=0.634)$, major satisfaction $(p=0.608)$, or satisfaction with college life $(p=0.956)$ between the flipped learning group and the lecture-based group (Table 1).

\subsection{Homogeneity for Dependent Variables}

The homogeneity for dependable variables in the two groups is shown in Table 2. The results of the independent $t$-test indicated that before the intervention, there were no significant differences between the groups in terms of the mean scores of the critical thinking, problem solving ability, and self-leadership. There were also no significant differences in the subscales of problem-solving ability and self-leadership between groups (Table 2).

\subsection{Critical Thinking, Problem Solving Ability, Self-Leadership, and Class Satisfaction}

In the analysis with a mixed model considering repetition to confirm the between- and inner-groups effects, there was no significant difference in critical thinking ability ( $\mathrm{F}=2.61$, $p=0.108$ ), but there was a statistically significant difference in problem-solving ability $(\mathrm{F}=8.08, p=0.005)$ and self-leadership $(\mathrm{F}=5.29, p=0.023)$ (Table 3). Critical thinking showed a minor improvement on the post test in the flipped learning group, but the difference between groups in the pre and post test was not statistically significant $(t=1.61$, $p=0.108$ ). For example, the mean scores of critical thinking improved to $0.07 \pm 0.27$ for the flipped learning group after the intervention but decreased to $0.00 \pm 0.27$ for the lecture-based group (Table 4). 
Table 3. Differences in pre- and post-intervention outcomes between the flipped learning and lecture-based groups $(\mathrm{N}=154)$.

\begin{tabular}{|c|c|c|c|c|c|c|}
\hline Variables & Time & $\begin{array}{l}\text { Flipped Learning } \\
\text { Group }(n=75)\end{array}$ & $\begin{array}{l}\text { Lecture-Based } \\
\text { Group }(n=79)\end{array}$ & Source & $\mathrm{F}(p)$ & Effect Size \\
\hline \multirow[t]{3}{*}{ Critical thinking } & Pre Test & $3.61 \pm 0.29$ & $3.60 \pm 0.40$ & Group & $0.00(0.948)$ & 0.003 \\
\hline & Post Test & $3.67 \pm 0.29$ & $3.60 \pm 0.41$ & Time & $4.72(0.031)$ & 0.015 \\
\hline & & & & Group * Time & 2.61(0.108) & 0.017 \\
\hline \multirow[t]{3}{*}{ Problem-solving ability } & Pre Test & $3.52 \pm 0.42$ & $3.62 \pm 0.50$ & Group & $1.61(0.206)$ & $<0.001$ \\
\hline & Post Test & $3.63 \pm 0.42$ & $3.53 \pm 0.50$ & Time & $4.84(0.029)$ & 0.001 \\
\hline & & & & Group * Time & $8.08(0.005)$ & 0.050 \\
\hline \multirow[t]{3}{*}{ Clarifying a problem } & Pre Test & $3.74 \pm 0.47$ & $3.81 \pm 0.52$ & Group & $0.77(0.382)$ & 0.006 \\
\hline & Post Test & $3.72 \pm 0.46$ & $3.77 \pm 0.54$ & Time & $0.10(0.750)$ & 0.003 \\
\hline & & & & Group * Time & $0.03(0.864)$ & $<0.001$ \\
\hline \multirow[t]{3}{*}{ Seeking a solution } & Pre Test & $3.58 \pm 0.52$ & $3.62 \pm 0.59$ & Group & $0.24(0.628)$ & 0.005 \\
\hline & Post Test & $3.67 \pm 0.49$ & $3.49 \pm 0.57$ & Time & $2.02(0.157)$ & 0.001 \\
\hline & & & & Group * Time & $5.80(0.017)$ & 0.037 \\
\hline \multirow[t]{3}{*}{ Decision making } & Pre Test & $3.57 \pm 0.53$ & $3.71 \pm 0.65$ & Group & $2.35(0.126)$ & 0.006 \\
\hline & Post Test & $3.53 \pm 0.54$ & $3.54 \pm 0.65$ & Time & $0.27(0.603)$ & 0.026 \\
\hline & & & & Group * Time & $1.65(0.201)$ & 0.011 \\
\hline \multirow[t]{3}{*}{ Applying a solution } & Pre Test & $3.51 \pm 0.54$ & $3.57 \pm 0.52$ & Group & $0.44(0.505)$ & 0.002 \\
\hline & Post Test & $3.65 \pm 0.61$ & $3.51 \pm 0.58$ & Time & $3.85(0.052)$ & 0.004 \\
\hline & & & & Group*Time & $4.30(0.040)$ & 0.028 \\
\hline \multirow[t]{3}{*}{ Evaluation and reflection } & Pre Test & $3.22 \pm 0.61$ & $3.37 \pm 0.76$ & Group & $2.17(0.142)$ & 0.004 \\
\hline & Post Test & $3.61 \pm 0.46$ & $3.31 \pm 0.74$ & Time & $24.54(<0.001)$ & 0.055 \\
\hline & & & & Group * Time & $17.02(<0.001)$ & 0.101 \\
\hline \multirow{3}{*}{ Self-leadership } & Pre Test & $3.54 \pm 0.38$ & $3.52 \pm 0.44$ & Group & $0.04(0.852)$ & 0.014 \\
\hline & Post Test & $3.66 \pm 0.49$ & $3.49 \pm 0.46$ & Time & $6.95(0.009)$ & 0.014 \\
\hline & & & & Group * Time & $5.29(0.023)$ & 0.034 \\
\hline \multirow[t]{3}{*}{ Behavior-focused strategies } & Pre Test & $3.65 \pm 0.43$ & $3.63 \pm 0.47$ & Group & $0.04(0.846)$ & 0.002 \\
\hline & Post Test & $3.70 \pm 0.50$ & $3.65 \pm 0.48$ & Time & $0.95(0.331)$ & 0.005 \\
\hline & & & & Group * Time & $0.27(0.607)$ & 0.002 \\
\hline \multirow[t]{3}{*}{ Natural reward strategies } & Pre Test & $3.25 \pm 0.63$ & $3.17 \pm 0.68$ & Group & $0.65(0.422)$ & 0.075 \\
\hline & Post Test & $3.62 \pm 0.66$ & $3.08 \pm 0.67$ & Time & $19.90(<0.001)$ & 0.036 \\
\hline & & & & Group * Time & $15.93(<0.001)$ & 0.095 \\
\hline \multirow[t]{3}{*}{ Constructive thought pattern strategies } & Pre Test & $3.49 \pm 0.55$ & $3.50 \pm 0.56$ & Group & $0.03(0.859)$ & 0.009 \\
\hline & Post Test & $3.64 \pm 0.57$ & $3.44 \pm 0.60$ & Time & $5.25(0.023)$ & 0.006 \\
\hline & & & & Group * Time & $5.43(0.021)$ & 0.034 \\
\hline
\end{tabular}

Problem solving improved significantly in the flipped learning group $(0.11 \pm 0.43)$ but decreased for the lecture-based group after intervention $(-0.09 \pm 0.45)(t=2.84, p=0.005)$. For the subscales of problem solving ability, the differences between changes in the two groups concerning seeking and applying a solution were significant $(p=0.017 ; p=0.040)$. In the lecture-based group, the mean scores decreased by $-0.13 \pm 0.58$ and $-0.06 \pm 0.62$, while the flipped learning group mean scores improved by $0.09 \pm 0.55$ and $0.14 \pm 0.58$ after intervention. In addition, evaluation and reflection improved significantly in the flipped learning group $(0.39 \pm 0.62)$ but decreased for the lecture-based group $(-0.06 \pm 0.74)$ $(t=4.13, p<0.001)$ after intervention (Table 3).

Self-leadership in the flipped learning group improved significantly $(0.13 \pm 0.43)$, while it decreased in the lecture-based group $(-0.03 \pm 0.42)(p=0.023)$. Among the subscales of self-leadership, the flipped learning group $(0.37 \pm 0.80)$ showed significant improvement in natural reward strategies in comparison to the lecture-based group $(-0.09 \pm 0.63)(p<0.001)$. In addition, the mean scores for constructive thought pattern strategies improved for the flipped learning group $(0.15 \pm 0.60)$ but decreased for the lecture-based group $(-0.06 \pm 0.54)(p=0.021)$ after intervention (Table 3$)$.

The participants in the flipped learning group $(4.12 \pm 0.72)$ were more satisfied with the course than those in the lecture-based group (3.80 \pm 0.84$)$. Class satisfaction significantly differed between the flipped learning group and the lecture-based group $(p=0.013)$ (Table 3). 
Table 4. Differences in pre- and post-intervention outcomes between the flipped learning and lecture-based groups $(\mathrm{N}=154)$.

\begin{tabular}{|c|c|c|c|c|c|c|c|}
\hline \multirow{2}{*}{ Variables } & \multicolumn{2}{|c|}{$\begin{array}{l}\text { Flipped Learning Group } \\
\qquad(n=75)\end{array}$} & \multicolumn{2}{|c|}{$\begin{array}{l}\text { Lecture-Based Group } \\
\qquad(n=79)\end{array}$} & \multicolumn{2}{|c|}{ Group Differences in Pre and Post Test } & \multirow{2}{*}{$t$} \\
\hline & Pre Test & Post Test & Pre Test & Post Test & $\begin{array}{c}\text { Flipped Learning } \\
\text { Group }\end{array}$ & $\begin{array}{l}\text { Lecture-Based } \\
\text { Group }\end{array}$ & \\
\hline Critical thinking & $3.60 \pm 0.29$ & $3.67 \pm 0.29$ & $3.60 \pm 0.40$ & $3.60 \pm 0.41$ & $0.07 \pm 0.27$ & $-0.00 \pm 0.27$ & $1.61(0.108)$ \\
\hline Problem-solving ability & $3.52 \pm 0.42$ & $3.63 \pm 0.42$ & $3.62 \pm 0.50$ & $3.53 \pm 0.50$ & $0.11 \pm 0.43$ & $-0.09 \pm 0.45$ & $2.84(0.005)$ \\
\hline Clarifying a problem & $3.73 \pm 0.46$ & $3.71 \pm 0.46$ & $3.80 \pm 0.52$ & $3.77 \pm 0.53$ & $-0.02 \pm 0.53$ & $-0.04 \pm 0.60$ & $0.17(0.864)$ \\
\hline Seeking a solution & $3.57 \pm 0.51$ & $3.67 \pm 0.49$ & $3.62 \pm 0.59$ & $3.49 \pm 0.56$ & $0.09 \pm 0.55$ & $-0.13 \pm 0.58$ & $2.41(0.017)$ \\
\hline Decision making & $3.56 \pm 0.52$ & $3.52 \pm 0.54$ & $3.71 \pm 0.65$ & $3.54 \pm 0.65$ & $-0.04 \pm 0.67$ & $-0.17 \pm 0.63$ & $1.29(0.152)$ \\
\hline Applying a solution & $3.51 \pm 0.53$ & $3.64 \pm 0.60$ & $3.57 \pm 0.51$ & $3.50 \pm 0.58$ & $0.14 \pm 0.58$ & $-0.06 \pm 0.62$ & $2.07(0.040)$ \\
\hline Evaluation and reflection & $3.21 \pm 0.61$ & $3.60 \pm 0.45$ & $3.37 \pm 0.75$ & $3.30 \pm 0.73$ & $0.39 \pm 0.62$ & $-0.06 \pm 0.74$ & $4.13(<0.001)$ \\
\hline Self-leadership & $3.54 \pm 0.38$ & $3.67 \pm 0.49$ & $3.52 \pm 0.44$ & $3.49 \pm 0.46$ & $0.13 \pm 0.43$ & $-0.03 \pm 0.42$ & $2.30(0.023)$ \\
\hline Behavior-focused strategies & $3.65 \pm 0.43$ & $3.70 \pm 0.50$ & $3.63 \pm 0.47$ & $3.65 \pm 0.48$ & $0.05 \pm 0.45$ & $0.01 \pm 0.45$ & $0.52(0.607)$ \\
\hline Natural reward strategies & $3.25 \pm 0.63$ & $3.62 \pm 0.66$ & $3.17 \pm 0.68$ & $3.08 \pm 0.67$ & $0.37 \pm 0.80$ & $-0.09 \pm 0.63$ & $4.00(<0.001)$ \\
\hline $\begin{array}{l}\text { Constructive thought } \\
\text { pattern strategies }\end{array}$ & $3.49 \pm 0.55$ & $3.64 \pm 0.57$ & $3.50 \pm 0.56$ & $3.44 \pm 0.60$ & $0.15 \pm 0.60$ & $-0.06 \pm 0.54$ & $2.33(0.021)$ \\
\hline Satisfaction with class & & $4.12 \pm 0.72$ & & $3.80 \pm 0.84$ & & & $2.52(0.013)$ \\
\hline
\end{tabular}

\section{Discussion}

The aim of this study was to evaluate the effects of applying the flipped learning approach in an anatomy class for nursing students. In this study, flipped learning was more effective at enhancing nursing students' self-leadership than traditional lecturebased learning. Flipped learning was also more effective at improving the evaluation and reflection sub-domains of problem-solving ability than traditional lecture-based learning. The results were consistent when analyzed with a mixed model considering repetition to confirm between- and inner-group effects. In addition, nursing students who participated in flipped learning showed higher satisfaction with the classes than those who participated in traditional lecture-based learning.

These findings support previous studies on nursing students in which self-leadership was higher in the flipped learning group than in the lecture-based group [6]. Our study demonstrated that flipped learning is more effective than lecture-based learning at improving natural rewards and constructive thought strategies among the sub-domains of self-leadership. Self-leadership is the process by which individuals regulate their own behavior, typically accomplished through the use of rewards as well as behavioral and cognitive strategies [27]. Improving nursing students' rewards and constructive thought strategies leads to positive thinking when accomplishing their goals; such students will utilize such methods to praise themselves when finally fulfilling their goals [37]. Many nursing students have difficulty in an anatomy class as they must memorize many medical terms [38]. However, since the nursing students in the flipped learning group can study many medical terms online before class, it is thought that they could more easily understand the content during class. In addition, in the flipped approach, students may review content multiple times, anytime, anywhere using self-paced e-learning tools, until they understand completely. During class, student-centered interactions help students to take control of their own learning. It is easier for nursing students in the flipped learning group to achieve the goals of an anatomy class than those in the traditional lecture-based group. Therefore, nursing students in the flipped learning group achieved the class goals in a more positive manner than those in the traditional lecture-based group [37] and believed they could accomplish these goals by themselves [27].

Our results revealed improvements in seeking a solution, applying a solution, and evaluation and reflection among the sub-domains of problem-solving ability among students who learned anatomy via the flipped learning approach compared to traditional lecture-based methods. In the flipped approach, students can view the online lectures repeatedly until they completely understand, thus offering more flexibility than traditional lectures. In addition, flipped learning gives students the chance to discuss topics they are struggling with during class time and extend the active learning experience after class 
through individual work or additional collaborations. It can be expected that this process will help nursing students better seek and apply solutions, as well as improve evaluation and reflection by providing time for them to continue practicing these skills after class. However, there were no differences between nursing students in the flipped learning group and students in the lecture-based group in terms of clarifying problems and decision making (viewed as sub-domains of problem-solving ability), which is similar to the results of Lee and Park [6]. Since the goal of an anatomy class is to provide basic knowledge for solving nursing problems [38], there may be limitations to improving problem clarification and decision making regarding anatomy. Given that flipped learning's effectiveness at improving all sub-domains of problem-solving ability has yet to be determined [7], future research will be needed to clarify if flipped learning in an anatomy class leads to such improvements.

Our results are consistent with those of previous studies, suggesting that class satisfaction is greater among students taught using flipped learning approaches than taught using lectured-based approaches [33,39]. This means that students in the flipped classroom felt more satisfaction with learning or performance in the class and enjoyed positive learning experiences due to the enhanced interaction and engagement through small group discussions and student group presentations [40]. Flipped learning is also referred to as active learning, which is a student-centered teaching technique that encourages students to increase their understanding of the subject material, interact with their peers, and recognize positive perceptions [41].

Critical thinking showed minor improvements on the post test in the flipped learning group but was not statistically significant. Anatomy is a subject comprising biological nursing science knowledge and is important in the early stages of the nursing curriculum [42]. Therefore, in this study it was difficult to include enough cases for reflection and analysis in clinical situations regarding improvements in critical thinking in an anatomy class. However, as critical thinking is important for nurses [20], further research that can foster critical thinking in anatomy classes will be needed.

Effect sizes are a common significant outcome of empirical studies and emphasize the importance of communicating the practical significance of results. Considering the effect size, evaluation and reflection among sub-domains of problem-solving ability was most improved in the flipped learning group compared to the control group. The effect size of evaluation and reflection was 0.101 , which was small. Nevertheless, this study has external validity due to its consistency with the results of previous studies $[6,33,39]$ of flipped learning for nursing students. This study also has internal validity because the control and flipped learning groups were homogeneous before intervention [43]. These groups maintained a similar educational environment during the intervention except for the flipped learning. The data were analyzed using a mixed model to confirm betweenand inner-group effects. In addition, the internal reliability of the tools used in this study was 0.89 or higher, and the reliability of the study results was very high [44].

We found that flipped learning in nursing anatomy classes improved the students' ability to seek solutions, apply solutions, the evaluation and reflection sub-domains of problem-solving ability, and the natural rewards and constructive thought strategy subdomains of self-leadership among nursing students. However, since flipped learning approaches have disadvantages such as lack of adaptation to new learning, lack of technical support, and psychological burden $[45,46]$, it is necessary to build flipped learning curricula from the ground up while considering these problems. Nursing students are required to become skilled at problem solving and self-leadership to establish their priorities in multiple nursing settings, as nurses must deal effectively with decision making in complex clinical settings where information and clinical situations are constantly changing [22]. We have demonstrated the utility of flipped learning, which may lead to active student-centered approaches and more dynamic methods to increase students' attention and empower students to better understand content by creating more satisfying learning experiences $[47,48]$. Additionally, during the COVID-19 pandemic, in comparison with the effects of lecture-based 
learning, nursing instructors can consider modified flipped learning education $[49,50]$. Furthermore, the use of virtual reality technology in anatomy teaching can increase interest and improve academic achievement and student satisfaction [51]. Therefore, future studies should investigate the effects of modified flipped learning, applying the use of virtual reality as a supplement.

\section{Limitations and Recommendations}

This study has some limitations. First, the study was conducted among nursing students at two universities in South Korea, and, therefore the results of this study may not be generalizable to other contexts. Second, the researchers designed the study so participants received the same treatment regardless of learning approach; however, the fact that students from other universities were educated by other instructors may have affected these results. Therefore, utilizing methods such as randomized control trials or meta-analysis is necessary to fully identify and generalize the effects of flipped learning on problem solving ability and self-leadership in an anatomy class.

\section{Conclusions}

In this study, we aimed to evaluate the effect of applying a flipped learning approach in an anatomy class among nursing students. The two groups consisted of a flipped learning group and a lecture-based group. The anatomy class was administered to each group as a weekly 2-h class for 15 weeks for nursing students. The flipped learning approach was shown to improve problem-solving ability, self-leadership, and class satisfaction compared to lecture-based learning in an anatomy class. Compared with lectured-based learning, the flipped learning approach fosters interactive learning activities, which better support the needs of advanced learners and provide more chances for problem solving and selfleadership than lecture-based approaches.

Author Contributions: Conceptualization, Y.H. and J.O.; methodology, Y.H. and J.O.; software, Y.H.; validation J.O.; formal analysis, J.O.; intervention, Y.H. and J.O.; resources, Y.H.; data curation, Y.H.; writing original draft preparation, Y.H. and J.O.; writing-review and editing, Y.H. and J.O.; visualization, J.O.; supervision, Y.H.; project administration, J.O. All authors have read and agreed to the published version of the manuscript.

Funding: This research received no external funding.

Institutional Review Board Statement: The study was approved by the Institutional Review Board of the University.

Informed Consent Statement: Informed consent was obtained from all subjects involved in the study.

Data Availability Statement: The data presented in this study are available on request from the corresponding author. The data are not publicly available due to privacy.

Conflicts of Interest: The authors declare no conflict of interest.

\section{References}

1. Diño, M.J.S.; Ong, I.L. Research, technology, education and scholarship in the fourth Industrial Revolution [4IR]: Influences in nursing and the health sciences. J. Med. Investig. 2019, 66, 3-7. [CrossRef] [PubMed]

2. Yoon, D. What we need to prepare for the fourth industrial revolution. Healthc. Inform. Res. 2017, 23, 75-76. [CrossRef] [PubMed]

3. Kim, K.J.; Jang, B.Y.; Jung, J.Y.; Park, O.W. The coming of the 4th industrial revolution and the HRD issues for nurses-Prospects and challenges. Korean J. Resour. Dev. 2018, 21, 137-159. [CrossRef]

4. Choi, E.; Lindquist, R.; Song, Y. Effects of problem-based learning vs. traditional lecture on Korean nursing students' critical thinking, problem-solving, and self-directed learning. Nurse Educ. Today 2014, 34, 52-56. [CrossRef] [PubMed]

5. Lee, K.E. Effects of team-based learning on the core competencies of nursing students: A quasi-experimental study. J. Nurs. Res. 2018, 26, 88-96. [CrossRef]

6. Lee, M.K.; Park, B.K. Effects of flipped learning using online materials in a surgical nursing practicum: A pilot stratified group-randomized trial. Healthc. Inform. Res. 2018, 24, 69-78. [CrossRef] [PubMed]

7. Ward, M.; Knowlton, M.C.; Laney, C.W. The flip side of traditional nursing education: A literature review. Nurse Educ. Pract. 2018, 29, 163-171. [CrossRef] 
8. Zarifsanaiey, N.; Amini, M.; Saadat, F. A comparison of educational strategies for the acquisition of nursing student's performance and critical thinking: Simulation-based training vs. integrated training (simulation and critical thinking strategies). BMC Med. Educ. 2018, 16, 294. [CrossRef]

9. Mollman, S.; Bondmass, M.D. Intentional learning: A student-centered pedagogy. Int. J. Nurs. Educ. Scholarsh. 2020, 17, 20190097. [CrossRef]

10. Levett-Jones, T.L. Self-directed learning: Implications and limitations for undergraduate nursing education. Nurse Educ. Today 2005, 25, 363-368. [CrossRef]

11. Leidl, D.M.; Ritchie, L.; Moslemi, N. Blended learning in undergraduate nursing education-A scoping review. Nurse Educ. Today 2005, 86, 104318. [CrossRef] [PubMed]

12. Bang, J.H.; Lee, J.H. Exploring educational significance of flipped classroom and its implications for instructional design. J. Korean Teach. Educ. 2014, 31, 299-319. [CrossRef]

13. Bergmann, J.; Sams, A. Flip Your Classroom: Reach Every Student in Every Class Every Day; International Society for Technology in Education: Eugene, OR, USA, 2012.

14. Bates, S.; Galloway, R. The Inverted Classroom in a Large Enrolment Introductory Physics Course: A Case Study. In Proceedings of the HEA STEM Learning and Teaching Conference, London, UK, 12-13 April 2012.

15. Enfield, J. Looking at the impact of the flipped classroom model of instruction on undergraduate multimedia students at CSUN. TechTrends 2013, 57, 14-27. [CrossRef]

16. Kim, N.; Chun, B.A.; Choi, J. A case study of flipped learning at college: Focused on effects of motivation and self-efficacy. J. Educ. Technol. 2014, 30, 467-492. [CrossRef]

17. Benner, P.; Sutphen, M.; Leonard, V.; Day, L. Educating Nurses: A Call for Radical Transformation; John Wiley \& Sons: New York, NY, USA, 2009; Volume 15.

18. Youk, J. The impact of the learner-centered teaching on improving critical thinking strategies: Based on the flipped learning. Korean J. Converg. Humanit. 2016, 4, 55-72. [CrossRef]

19. Hendricson, W.D.; Andrieu, S.C.; Chadwick, D.G.; Chmar, J.E.; Cole, J.R.; George, M.C.; Glickman, G.N.; Glover, J.F.; Goldberg, J.S.; Haden, N.K.; et al. Educational strategies associated with development of problem-solving, critical thinking, and self-directed learning. J. Dent. Educ. 2006, 70, 925-936. [CrossRef]

20. Jiménez-Gómez, M.A.; Cárdenas-Becerril, L.; Velásquez-Oyola, M.B.; Carrillo-Pineda, M.; Barón-Díaz, L.Y. Reflective and critical thinking in nursing curriculum. Rev. Lat. Am. Enferm. 2019, 27, e3173. [CrossRef]

21. García-Sierra, R.; Fernández-Castro, J. Relationships between leadership, structural empowerment, and engagement in nurses J. Adv. Nurs. 2018, 74, 2809-2819. [CrossRef]

22. Papathanasiou, I.V.; Kleisiaris, C.F.; Fradelos, E.C.; Kakou, K.; Kourkouta, L. Critical thinking: The development of an essential skill for nursing students. Acta Inform. Med. 2014, 22, 283-286. [CrossRef] [PubMed]

23. Dehghanzadeh, S.; Jafaraghaee, F. Comparing the effects of traditional lecture and flipped classroom on nursing students ${ }^{\prime}$ critical $^{2}$ thinking disposition: A quasi-experimental study. Nurse Educ. Today 2018, 71, 151-156. [CrossRef]

24. Yoon, J. Development of an Instrument for the Measurement of Critical Thinking Disposition: In Nursing. Ph.D. Thesis, Catholic University of Korea, Seoul, Korea, 2004.

25. Hoyt, P. Problem Solving for Better Health Nursing: A working approach to the development and dissemination of applied research in developing countries. Appl. Nurs. Res. ANR 2006, 19, 110-112, discussion 112. [CrossRef] [PubMed]

26. Lee, W.-S.; Park, S.-H.; Choi, E.-Y. Development of a Korean problem solving process inventory for adults. J. Korean Acad. Fundam. Nurs 2008, 15, 548-557.

27. Neck, C. Self-Leadership [Electronic Resource]; Emerald Group Publishing Limited: Bradford, UK, 2006.

28. Kim, A.; Sim, I. Mediating Factors in Nursing Competency: A Structural Model Analysis for Nurse Communication, SelfLeadership, Self-Efficacy, and Nursing Performance. Int. J. Environ. Res. Public Health 2020, 17, 6850. [CrossRef] [PubMed]

29. Kan, J.-S.; Shin, M.-S.; Kwon, M.-S. The effects of project-based flipped learning model on self-directed learning ability, selfleadership and learning competency. J. Fish. Mar. Sci. Educ. 2016, 28, 1478-1491. [CrossRef]

30. Shin, Y.; Kim, M.-S.; Han, Y.-S. A study on the validation of the Korean version of the Revised Self-Leadership Questionnaire (RSLQ) for Korean college students. Korean J. Sch. Psychol. 2009, 6, 313-340.

31. Moore, K.B.; Bonnett, R.; Colbert-Getz, J.M. A Process and Rubric for a Group to Review the Quality of a Medical Education Course/Clerkship. MedEdPORTAL 2020, 16, 18. [CrossRef] [PubMed]

32. Lee, S.H. A study for instrument development of course evaluation in the university based upon the theory of instructional design. J. Educ. Technol. 2001, 17, 81-108. [CrossRef]

33. Alamri, M.M. Students' academic achievement performance and satisfaction in a flipped classroom in Saudi Arabia. Int. J. Technol. Enhanc. Learn. 2019, 11, 103-119. [CrossRef]

34. Faul, F.; Erdfelder, E.; Lang, A.G.; Buchner, A. G* Power 3: A flexible statistical power analysis program for the social, behavioral, and biomedical sciences. Behav. Res. Method 2007, 39, 175-191. [CrossRef]

35. Houghton, J.D.; Neck, C.P. The revised self-leadership questionnaire. J. Manag. Psychol. 2002, 17, 672-691. [CrossRef]

36. Dick, W.; Carey, L. The Systematic Design of Instruction; Pearson: Hoboken, NJ, USA, 2016.

37. Bryant, A. Self-Leadership, 1st ed.; McGraw-Hill Publishing: New York, NY, USA, 2012. 
38. Joseph, M.A.; Roach, E.J.; Natarajan, J.; Karkada, S.; Cayaban, A.R.R. Flipped classroom improves Omani nursing students performance and satisfaction in anatomy and physiology. BMC Nurs. 2021, 20, 1. [CrossRef] [PubMed]

39. He, Y.; Lu, J.; Huang, H.; He, S.; Ma, N.; Sha, Z.; Sun, Y.; Li, X. The effects of flipped classrooms on undergraduate pharmaceutical marketing learning: A clustered randomized controlled study. PLoS ONE 2019, 14, e0214624. [CrossRef]

40. Johnson, G.B. Student Perceptions of the Flipped Classroom. Master's Thesis, University of British Columbia, Okanagan, BC, Canada, 2013. Available online: https:/ / www.mdpi.com/authors/layout\#_bookmark53 (accessed on 1 October 2021).

41. Galway, L.P.; Corbett, K.K.; Takaro, T.K.; Tairyan, K.; Frank, E. A novel integration of online and flipped classroom instructional models in public health higher education. BMC Med. Educ. 2014, 14, 181. [CrossRef]

42. Brown, S.J.; White, S.; Power, N. Introductory anatomy and physiology in an undergraduate nursing curriculum. Adv. Physiol. Educ. 2017, 41, 56-61. [CrossRef] [PubMed]

43. Slack, M.K.; Draugalis, J.R.J. Establishing the internal and external validity of experimental studies. Am. J. Health-Syst. Pharm. 2001, 58, 2173-2181. [CrossRef] [PubMed]

44. Heale, R.; Twycross, A. Validity and reliability in quantitative studies. Evid. Based Nurs. 2015, 18, 66-67. [CrossRef] [PubMed]

45. Kellesarian, S.V. Flipping the dental anatomy classroom. Dent. J. 2018, 6, 23. [CrossRef]

46. Lee, B.; Hwang, S.Y. Class experience of the students on [pregnancy, delivery and puerperium] nursing course through flipped learning: Mixed method research. Korean J. Women Health Nurs. 2016, 22, 221-232. [CrossRef]

47. Missildine, K.; Fountain, R.; Summers, L.; Gosselin, K. Flipping the classroom to improve student performance and satisfaction. J. Nurs. Educ. 2013, 52, 597-599. [CrossRef]

48. Tune, J.D.; Sturek, M.; Basile, D.P. Flipped classroom model improves graduate student performance in cardiovascular, respiratory, and renal physiology. Adv. Physiol. Educ. 2013, 37, 316-320. [CrossRef] [PubMed]

49. Alsaywid, B.; Lytras, M.D.; Abuzenada, M.; Lytra, H.; Housawi, A.; Abuznadah, W.; Alhaidar, S.A.; Apostolaki, A.; Sultan, L.; Badawoud, H. Effectiveness and Preparedness of Institutions' E-learning Method During COVID-19 Pandemic for residents' medical training in Saudi Arabia: A pilot study. Front. Public Health 2021, 9, 1021. [CrossRef] [PubMed]

50. Cheng, H.-C.; Lu, S.-L.; Yen, Y.-C.; Siewchaisakul, P.; Yen, A.M.-F.; Chen, S.L.-S. Dental education changed by COVID-19: Student's perceptions and attitudes. BMC Med. Educ. 2021, 21, 364. [CrossRef] [PubMed]

51. Zhao, J.; Xu, X.; Jiang, H.; Ding, Y. The effectiveness of virtual reality-based technology on anatomy teaching: A meta-analysis of randomized controlled studies. BMC Med. Educ. 2020, 20, 127. [CrossRef] [PubMed] 